\title{
THE OPTIMIZATION OF THE EXTRACTION PROCESS OF FLAVONOIDS FROM FERMENTED CHAMOMILE LIGULATE FLOWERS
}

Zoran P. Zeković ${ }^{1}$, Aleksandra D. Cvetanović ${ }^{*}$, Branimir M. Pavlić1, Jaroslava V. Švarc-Gajić ${ }^{2}$ Marija M. Radojković ${ }^{1}$

${ }^{1}$ Department of Biotechnology and Pharmaceutical Engineering Faculty of Technology, University of Novi Sad, Novi Sad, Serbia

2Department for Applied and Engineering Chemistry Faculty of Technology, University of Novi Sad, Novi Sad, Serbia

Response surface methodology (RSM) was applied in order to examine the influence of extraction parameters on the extraction yield of total phenols (TP), total flavonoids (TF) and apigenin (A) from autofermented chamomile ligulate flowers (A-CLF) extracts. Temperature, the ethanol concentration and extraction time were selected as independent variables, and their values were selected on the basis of preliminary experimental results and literature data. The Box-Behnken experimental design which was applied consisted of 17 experimental runs with five replicates at the central point. A second-order polynomial model was used for predicting the response. Defined optimal conditions for maximizing yields of TP, TF and A included the extraction temperature of $80^{\circ} \mathrm{C}$, ethanol concentration of $62 \%$ and extraction time of $50.4 \mathrm{~min}$, whereas the maximum yields of apigenin could be expected at the temperature of $73.6{ }^{\circ} \mathrm{C}$, the solvent concentration of $60.8 \%$ and the extraction time of 46 min. The verification of the experimental process was done at previously defined optimal conditions. The experimental values agreed with those predicted thus indicating suitability of the used model and the success of RSM in optimizing the extraction conditions.
(ORIGINAL SCIENTIFIC PAPER) UDC 547.972.3
Keywords: Chamomile; response surface methodology (RSM); optimization; polyphenolics; apigenin.

\section{Introduction}

Chamomilla recutita (L.) or simply chamomile is one of the most popular and well documented medicinal plants whose flower-heads are used both internally and externally to alleviate or even cure a vast list of health conditions [1]. Although used in different pharmaceutical formulations [2-5], chamomile is mostly consumed as infusion for sedative and anxiolytic purposes [6-8], as a digestive and to treat gastrointestinal disturbances, especially in babies and children [9-11]. Bioactivity and potential health benefits of chamomile are associated with essential oil and flavonoids fraction. Among other flavonoids, researchers focus special attention on apigenin.

Apigenin is a flavonoid belonging to the flavone structural class, chemically known as 4',5,7,-trihydroxyflavone [12]. It is a central benzodiazepine receptor-ligand with anxiolytic effects, responsible for the sedative effect of the chamomile [3-13]. It has been shown that apigenin has the chemopreventive activity against UV-radiation and/or anti-cancer properties against a number of tumour types. This compound shows strong cytostatic and anti-angiogenic effects in vitro and was found to be an inhibitor of protein kinases. Furthermore, apigenin induces apoptosis in breast cancer cells through proteasomal degradation [14]. Recently, it has been discovered that apigenin inhibits hypoxia-activated pathways linked to cancer progression in human prostate cancer $[15,16]$.

Apigenin accumulates in white ligulate flowers of the chamomile anthodium in a bound form as apigenin 7-Oglucoside (Ap-7-Glc) and various acylated derivatives [17]. There are many reports showing that hydrolysis of Ap-7-Glc (the main glucoside in chamomile) into apigenin could be done prior extraction [18-20]. The fermentation process activates $\beta$-glucosidase, normally present in CLF. The action of this enzyme breaks glycoside links between aglycone and a sugar component in the molecule of Ap-7-Glc, releasing a free aglycone - apigenin. Response surface methodology (RSM) is an effective statistical technique for optimizing complex processes because it allows the more efficient and easier arrangement and interpretation of experiments compared to other methods [21-23]. In addition, it is less laborious and time-consuming than other optimization approaches [24]. RSM is widely used in optimizing the extraction process of bioactive compounds [25-28].

Taking into account that, depending on the polyphenolic composition the extracts obtained from fermented chamomile ligulate flowers may have a different biological potential [29], the aim of this study was to determine

\footnotetext{
*Author address: Aleksandra Cvetanović, Department of Biotechnology and Pharmaceutical Engineering, University of Novi Sad, Bulevar Cara Lazara 1, 21000 Novi Sad, Serbia

E-mail: a.c.istrazivac@gmail.com

The manuscript received: December, 1, 2014

Paper accepted: January, 22, 2015.
} 
the optimal extraction conditions for the extraction of autofermented chamomile ligulate flowers (A-CLF) in order to obtain the highest yields of phenols, flavonoids and apigenin. The study included the investigation of the influence of the extraction temperature $\left(40,60,80^{\circ} \mathrm{C}\right)$, solvent concentration $(50,70,90 \%)$ and extraction time (20, $40,60 \mathrm{~min}$ ) on the observed responses (total phenolic, total flavonoid and apigenin yields).

\section{Experimental}

Chemicals and reagents

Folin-Ciocalteu reagent, chlorogenic acid and rutin were purchased from Sigma-Aldrich (St. Louis, Missouri, USA). Aluminium chloride hexahydrate, sodium carbonate, and sodium acetate trihydrate were purchased from Merck (Darmstadt, Germany). Apigenin standard was produced by Extrasynthese (Genay, France). All other chemicals and reagents were analytical reagent grade.

Plant material and sample preparation

Chamomile ligulate flowers (CLF) used in this study were produced by the Institute of Field and Vegetable Crops, Bački Petrovac, Serbia, in the spring of 2011. Chamomile flos were dried at the temperature of $40^{\circ} \mathrm{C}$ in the solar dryer. The layer thickness of the plant material was $5 \mathrm{~cm}$. Drying was completed after the moisture of the plant material was approximately $12 \%$. Ligulate flowers were separated from other parts of the inflorescence by sifting through sieves. CLF were packed in paper bags and stored in the dark until use.

The process of autofermentation was performed according to the procedure previously described by Zeković et.al., [18]. The process was performed with sodium-acetate buffer $\left(0.1 \mathrm{~mol} / \mathrm{dm}^{3}, \mathrm{pH}=5.5\right)$ at $37^{\circ} \mathrm{C}$ during $72 \mathrm{~h}$. The plant: buffer ratio was 1:5 (w/v). The dry plant material was moisturized with the buffer and the mixture was stirred five times per day. The sample was further dried at room temperature for 5 days.

Autofermented samples were extracted using ethanol in different concentrations $(50,70,90 \%)$, at different temperatures $\left(40,60,80^{\circ} \mathrm{C}\right)$ and during different extraction times (20,40, $60 \mathrm{~min})$. Sample-solvent ratio was 1:50 (w/v). Liquid extracts were separated using filtration and stored at $4{ }^{\circ} \mathrm{C}$ until analysis.

\section{Selection of experimental conditions ranges}

This step was carried in order to define the solvent concentration, sample: solvent ratio, temperature and time that will be investigated. The solvent was selected after the extraction of A-CLF by three different solvents (water, methanol and ethanol) under the same conditions (room temperature and extraction time of $40 \mathrm{~min}$ ). Three different sample: solvent ratios were investigated using $70 \%$ ethanol for the extraction at room temperature during $40 \mathrm{~min}$. The obtained values of the extraction yield, total phenolic and total flavonoid contents were the input parameters for choosing the experimental conditions in this work. The selection of the extraction temperature and time was based on current literature data [25-28].

\section{Determination of total phenolics}

Total phenolics were determined spectrophotometrically using the Folin-Ciocalteu method $[30,31]$. The liquid extracts of A-CLF $(0.1 \mathrm{ml})$ were diluted with destilled water $(7.9 \mathrm{ml})$ to which $0.5 \mathrm{ml}$ of Folin-Ciocalteau reagent and sodium-carbonate $(20 \%, 1.5 \mathrm{ml})$ were added, and allowed to react at room temperature during 1 hour. Blank was prepared by using water instead of A-CLF liquid extract. The absorbance was measured at $750 \mathrm{~nm}$. Chlorogenic acid was used as a standard.

\section{Determination of total flavonoids}

Flavonoids in the A-CLF extracts were determined using colorimetric assay based on the procedure described by Markham [32]. A-CLF liquid extract $(1 \mathrm{ml})$ was mixed with $5 \% \mathrm{NaNO}_{2}$ solution $(0.3 \mathrm{ml})$. After 5 minutes, aluminium choride hexahydrate $(10 \%, 0.3 \mathrm{ml})$ was added and allowed to stand for further 6 minutes. Sodium-hidroxide $(1 \mathrm{M}, 1 \mathrm{ml})$ was added to the mixture. Immediately, the distilled water was properly added to bring the final volume to $10 \mathrm{ml}$. Blank was prepared using water instead of A-CLF liquid extract. The absorbance was measured at $510 \mathrm{~nm}$. Rutin was used as a reference standard.

Determination of apigenin by thin layer

chromatography (TLC)

Thin layer chromatography (TLC) was performed on $20 \times 20 \mathrm{~cm}$ glass plates (silica gel GF254, $0.5 \mathrm{~mm}$ thickness). The aliquots of A-CLF extracts $(50 \mu \mathrm{l})$ were spotted on the plate as start points. The mixture of toluene: ethylmethylcetone: methanol $(55: 30: 15, \mathrm{v} / \mathrm{v} / \mathrm{v})$ was used as a mobile phase. The development was performed at room temperature in a saturated glass chamber. Detection was done under UV light (254 and $365 \mathrm{~nm}$ ). Rf value of apigenin standard was used to identificate apigenin in the investigated extracts.

Spots of apigenin on silica gel were scraped and dissolved in $50 \%$ ethanol $(5 \mathrm{ml})$. After 30 min of intensive mixing, the mixture was centrifuged at $3000 \mathrm{~min}^{-1}$ for 10 min. The obtained supernatant, i.e. apigenin solution, was evaporated using nitrogen and after that dissolved in $5 \mathrm{ml}$ of $50 \%$ ethanol. The absorbance of the apigenin solution was measured at $340 \mathrm{~nm}$ [33].

\section{Experimental design}

Response surface methodology (RSM) with BoxBehnken experimental design was applied to identify the optimum levels of three variables: extraction temperature $\left(40,60,80^{\circ} \mathrm{C}\right)$, ethanol concentration $(50,70,90 \%$, $\mathrm{w} / \mathrm{w})$, and extraction time $(20,40,60 \mathrm{~min})$ regarding three responses - total phenolic, total flavonoid and apigenin contents in A-CLF extracts. The statistical analysis of the experiment was performed using Design-Expert v.7 Trial (Stat-Ease, Minneapolis, Minnesota, USA).

The coded and uncoded independent variables used 
in the RSM design are listed in Table 1 . The ranges of temperature $\left(X_{1}\right)$, ethanol $\left(X_{2}\right)$, time $\left(X_{3}\right)$ and the central points were selected based on preliminary experimental results and literature data.

Table 1. Uncoded and coded levels of independent variables and values of the observed independent variables, total phenolics (TP), total flavonoids (TF) and apigenin (A) contents

\begin{tabular}{ccccccc}
\hline Run & $\begin{array}{c}\text { Temperature } \\
{\left[{ }^{\circ} \mathbf{C}\right]}\end{array}$ & $\begin{array}{c}\text { Ethanol } \\
\text { Concentration } \\
{[\%]}\end{array}$ & $\begin{array}{c}\text { Time } \\
{[\mathrm{min}]}\end{array}$ & $\begin{array}{c}\text { TP }[\mathbf{m g} \\
\text { CAE/ml] }\end{array}$ & $\begin{array}{c}\text { TF }[\mathbf{m g} \\
\text { RE/ml] }\end{array}$ & A [mg/ml] \\
\hline 1 & $40(-1)$ & $50(-1)$ & $40(0)$ & 0.982 & 0.184 & 0.1306 \\
2 & $60(0)$ & $50(-1)$ & $20(-1)$ & 1.033 & 0.202 & 0.1410 \\
3 & $80(1)$ & $50(-1)$ & $40(0)$ & 1.245 & 0.228 & 0.1576 \\
4 & $60(0)$ & $50(-1)$ & $60(1)$ & 1.293 & 0.236 & 0.1774 \\
5 & $40(-1)$ & $70(0)$ & $20(-1)$ & 0.969 & 0.155 & 0.1230 \\
6 & $80(1)$ & $70(0)$ & $20(-1)$ & 1.200 & 0.215 & 0.1524 \\
7 & $60(0)$ & $90(1)$ & $20(-1)$ & 0.733 & 0.128 & 0.0884 \\
8 & $80(1)$ & $90(1)$ & $40(0)$ & 0.937 & 0.211 & 0.1438 \\
9 & $60(0)$ & $90(1)$ & $60(1)$ & 0.860 & 0.200 & 0.1300 \\
10 & $80(1)$ & $70(0)$ & $60(1)$ & 1.920 & 0.288 & 0.1536 \\
11 & $60(0)$ & $70(0)$ & $40(0)$ & 1.140 & 0.240 & 0.1628 \\
12 & $60(0)$ & $70(0)$ & $40(0)$ & 1.110 & 0.257 & 0.1790 \\
13 & $60(0)$ & $70(0)$ & $40(0)$ & 1.140 & 0.245 & 0.1634 \\
14 & $60(0)$ & $70(0)$ & $40(0)$ & 1.110 & 0.314 & 0.1624 \\
15 & $60(0)$ & $70(0)$ & $40(0)$ & 1.120 & 0.257 & 0.1582 \\
16 & $40(-1)$ & $90(1)$ & $40(0)$ & 0.770 & 0.147 & 0.1364 \\
17 & $40(-1)$ & $70(0)$ & $60(1)$ & 1.150 & 0.257 & 0.1582 \\
\hline
\end{tabular}

1 Chlorogenic acid equivalent

2 Rutin equivalent

The response variables were fitted to the following second-order polynomial model (Eq. 1) which was able to describe the relationship between the dependent output variable and the independent variables:

$$
Y=b_{0}+\sum b_{i} X_{i}+\sum b_{i i} X_{i i}^{2}+\sum b_{i j} X_{i} X_{j}
$$

where $Y$ represents the response variable (total phenolic, total flavonoid and apigenin contents); $X_{i}$ and $X_{j}$ are independent variables (temperature, ethanol concentration, extraction time); $\beta_{0}, \beta_{i}, \beta_{i i}$ and $\beta_{i j}$ are regression coefficients for intercept, linear, quadratic and interaction coefficient, respectively.

\section{Results and discussion}

Selection of the levels of independent variables

In general, the efficiency of the extraction is influenced by multiple parameters such as temperature, extraction time and solvent polarity among others, and their effects may be either independent or interactive [34].
Considering the specific structure of polyphenolic compounds, most of them are efficiently extracted with polar solvents. In order to choose the best solvent, three polar solvents were investigated. Table 2 represents the total extraction yield (TY) as well as the total amount of the extracted phenol (TP) and flavonoid compounds (TF) in the samples obtained with three different solvents. 
Table 2. Total extraction yield (TY), phenol (TP) and flavonoid (TF) contents in A-CLF extracts obtained with different solvents

\begin{tabular}{cccc}
\hline Solvent & TY $(\%)$ & TP $(\mathrm{mg} \mathrm{CAE} / \mathrm{mL})$ & TF $(\mathrm{mg} \mathrm{RE} / \mathrm{mL})$ \\
\hline Ethanol $(70 \%)$ & 31.00 & 67.45 & 15.32 \\
Methanol $(70 \%)$ & 31.20 & 65.21 & 15.08 \\
Water & 30.50 & 44.02 & 8.85 \\
\hline
\end{tabular}

Considering the total extraction yield, total phenolics and total flavonoids content, the mixture of ethanol and water was chosen as the best solvent, comparing to water and methanol. Other reasons for choosing the mixture of ethanol and water included the relative microbiological stability of the extracts and rather low toxicity comparing to other organic solvents. Sample:solvent ratio was investigated at three different levels (1:20, 1:30 and $1: 50 ; \mathrm{w} / \mathrm{v}$ ). The total yield of extractable compounds at $1: 20$ ratio was $30.80 \%$, at $1: 30$ it was $31.98 \%$ while the total amount of extractable compounds was the highest at $1: 50$ ratio $-33 \%$. The total extraction yield was increased with the sample: solvent ratio. Further increase in ratio is not desirable, due to practical reasons. Therefore, ratio 1:50 was maintained in all future experiments.

According to current literature $[25,28,35]$ the most common temperature range for the extraction of phenolic compounds is between 50 and $70^{\circ} \mathrm{C}$. This was the reason for choosing 40,60 and $80^{\circ} \mathrm{C}$ as lower, middle and upper levels of temperature. It is reported that the best extraction conditions for the apigenin extraction from A-CLF include $70 \%$ ethanol during $40 \mathrm{~min}$ [36]. Since the main focus of this study was put on the optimization of the apigenin extraction, previous conditions were chosen as middle levels for the experimental design. Lower and upper levels included were 50 and $90 \%$ ethanol. In terms of time, these levels were set at 20 and $60 \mathrm{~min}$.

Optimization of the extraction using RSM

Considering that extraction is a very important stage in isolation and, after that, the identification of bioactive compounds, there are many reports that aim to optimize the extraction process. RSM is a family of statistical techniques for the design, empirical modelling and optimization of processes, where the responses of interest are influenced by several process variables $[37,38]$.

To our knowledge, there are no reports on the optimization of apigenin extraction from A-CLF. In order to identify optimum variables regarding the three responses, RSM was applied. The experiments were designed according to RSM design, and the results are presented in Table 1 . The results were statistically tested by the analysis of variance (ANOVA) at a significance level of $p=0.05$.

Table 3. Regression coefficients of the predicted second-order model for the response variables, TP, TF and A

\begin{tabular}{|c|c|c|c|}
\hline $\begin{array}{l}\text { Regression } \\
\text { coefficient }\end{array}$ & TP & TF & A \\
\hline$\beta_{0}$ & $1.124^{* * *}$ & $0.262^{* *}$ & $0.165^{\star}$ \\
\hline \multicolumn{4}{|c|}{ Linear } \\
\hline$\beta_{1}$ & $0.178^{* \star *}$ & $0.024^{* *}$ & 0.007 \\
\hline$\beta_{2}$ & $-0.156^{* * *}$ & $-0.020^{*}$ & $-0.013^{* *}$ \\
\hline$\beta_{3}$ & $0.161^{\star \star \star}$ & $0.035^{\star \star \star}$ & $0.014^{* *}$ \\
\hline \multicolumn{4}{|c|}{ Crossproduct } \\
\hline$\beta_{12}$ & -0.024 & 0.005 & -0.004 \\
\hline$\beta_{13}$ & $0.134^{\star *}$ & -0.007 & -0.008 \\
\hline$\beta_{23}$ & -0.033 & 0.009 & 0.001 \\
\hline \multicolumn{4}{|c|}{ Quadratic } \\
\hline$\beta_{11}$ & 0.094 & -0.016 & -0.005 \\
\hline$\beta_{22}$ & $-0.235^{* * *}$ & $-0.053^{* * *}$ & $-0.017^{* *}$ \\
\hline$\beta_{33}$ & 0.091 & -0.017 & -0.013 \\
\hline $\mathbf{R}^{2 a}$ & 0.927 & 0.883 & 0.803 \\
\hline $\mathbf{C V}^{\mathrm{b}}$ & 9.734 & 11.512 & 10.019 \\
\hline $\begin{array}{l}{ }^{*} \text { Significant } \\
{ }^{* *} \text { Significant } \\
{ }^{* \star *} \text { Significan } \\
\text { a Coefficient } \\
\text { b Coefficient }\end{array}$ & rmination & & \\
\hline
\end{tabular}


Total phenolics content in A-CLF liquid extracts

At different investigated extraction conditions, the total phenolics content in A-CLF extracts varied from 0.770 to $1.920 \mathrm{mg} \mathrm{CAE} / \mathrm{ml}$. In the experiments, the highest TP content was obtained at the temperature of $80^{\circ} \mathrm{C}$ and ethanol concentration of $70 \%$ during $60 \mathrm{~min}$. The regression coefficients of models for TP, TF and A obtained by multiple linear regression are reported in Table 3.

A high value of the coefficient of multiple determination indicates the excellent fit of experimental and theoretical values. A relatively low value of the coefficient of variance also supports this claim. The total phenolics content was significantly influenced by the linear term of extraction parameters and by quadratic term of the solvent concentration $(p<0.01)$. The interaction between the extraction temperature and time demonstrated a sig- nificant effect on the phenolics content $(p<0.05)$. Due to a negative quadratic effect of $X_{2}$, it is indicated that there is a maximum in the TP yield at certain ethanol concentration. After this point, the yield of TP starts to decrease. The summarized analysis of variance (ANOVA) is represented in Table 4. According to F-value $(p<0.05)$ the fitted model represented the experimental data well. However, the lack of fit for this model is significant $(p<0.05)$. Therefore, it was not possible to generate a mathematical equation which would satisfactory describe the model on the investigated experimental range. A particularly high value of the lack of fit suggests that there is a significantly high deviation between the mean response at each level of independent variables and the corresponding fitted value [38].

Table 4. Analysis of variance (ANOVA) of the modelled responses

\begin{tabular}{|c|c|c|c|c|c|}
\hline Source & $\begin{array}{l}\text { Sum of } \\
\text { squares }\end{array}$ & $\mathbf{d f} \mathbf{f}^{\mathrm{a}}$ & Mean square & $F$-value & $p$-value \\
\hline \multicolumn{6}{|c|}{ Total phenolics content } \\
\hline Model & 1.029 & 9 & 0.114 & 9.966 & 0.003 \\
\hline Residual & 0.080 & 7 & 0.011 & & \\
\hline Lack of fit & 0.079 & 3 & 0.026 & 115.146 & 0.000 \\
\hline Pure error & 0.000 & 4 & 0.000 & & \\
\hline Total & 1.110 & 16 & & & \\
\hline \multicolumn{6}{|c|}{ Total flavonoids content } \\
\hline Model & 0.034 & 9 & 0.003 & 5.894 & 0.014 \\
\hline Residual & 0.004 & 7 & 0.000 & & \\
\hline Lack of fit & 0.001 & 3 & 0.000 & 0.387 & 0.769 \\
\hline Pure error & 0.003 & 4 & 0.000 & & \\
\hline Total & 0.039 & 16 & & & \\
\hline \multicolumn{6}{|c|}{ Apigenin content } \\
\hline Model & 0.006 & 9 & 0.000 & 3.178 & 0.070 \\
\hline Residual & 0.001 & 7 & 0.000 & & \\
\hline Lack of fit & 0.001 & 3 & 0.000 & 6.689 & 0.048 \\
\hline Pure error & 0.000 & 4 & 0.000 & & \\
\hline Total & 0.007 & 16 & & & \\
\hline
\end{tabular}
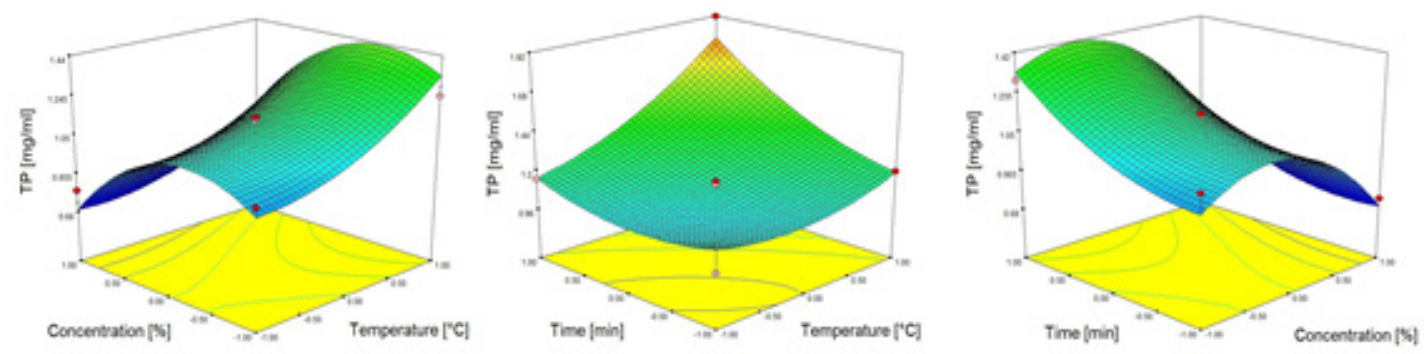

Figure 1. The influence of the investigated parameters on total phenolics content 
The visualization of the parameters influence could be accomplished by charts presented in Figure 1. It can be seen that the total phenolics content of A-CLF liquid extract increased with the temperature and with time. The ethanol concentration also had a significant influence on the phenolic content. Figure 1 shows that the total phenols content increased with the concentration of ethanol up to approximately $70 \%$. A further increase in the concentration caused a decrease in the phenolics content.

Total flavonoids content in A-CLF liquid extracts

The total flavonoids content of A-CLF liquid extracts varied from 0.128 to $0.314 \mathrm{mg} \mathrm{RE} / \mathrm{ml}$ (Table 1 ). The highest TF content was obtained by applying the following experimental conditions: temperature of $60{ }^{\circ} \mathrm{C}$, ethanol concentration of $70 \%$ and extraction time of $40 \mathrm{~min}$. A relatively high value of the coefficient of multiple determination indicates a good fit of experimental and theoretical values (Table 2). The coefficient of variance was rather low, supporting the fitness of the model. The total flavonoids content was significantly influenced by linear terms of extraction parameters, particularly by time $(p<0.01)$, and by quadratic term of the ethanol concentration. The interaction between independent variables turned out to be insignificant $(p>0.1)$. Due to the negative quadratic effect of $X_{2}$, it is indicated that there is a maximum in the TF yield at certain ethanol concentration. After this point, the yield of TF starts to decrease, as it was the case with TP. According to ANOVA for the modelled response, the fitted model represented the experimental data well with the high correlation coefficient $\left(R^{2}\right)$ and F-value $(p<0.05)$. Moreover, the lack of fit, which measures the fitness of the model, resulted in no significant F-value $(p>0.05)$ in terms of the response variable studied, indicating that the model was sufficiently accurate for predicting the response variations (Table 3 ).

The effects of independent variables on total flavonoids content of A-CLF could be described by the following equation:

$$
\begin{aligned}
& Y=0.2626+0.024875 X_{1}-0.0205 X_{2}+0.035125 X_{3}- \\
& -0.016425 X_{1}^{2}-0.052675 X_{2}^{2}-0.017425 X_{3}^{2}+ \\
& +0.005 X_{1} X_{2}-0.00725 X_{1} X_{2}+0.0095 X_{2} X_{3} \ldots \ldots \ldots \ldots \ldots
\end{aligned}
$$

where $Y$ represents TF content, while $X_{1}, X_{2}$ and $X_{3}$ represent independent variables.

The influence of the extraction parameters is presented in Figure 2. It can be seen that the highest values for the total flavonoids content were obtained for upper levels of temperature and time. With the increase of the ethanol concentration up to approximately $70 \%$ the increase of the TF was observed, while a further increase caused the decrease of the output value, which is in correlation with the regression coefficient for concentration. This indicates that there is a saddle point near $70 \%$ ethanol concentration. This is related to the fact that the extraction of flavonoid compounds depends on the polarity of a solvent. The mixture of ethanol and water offers modified polarity which is particularly suitable for the extraction of this type of compounds.
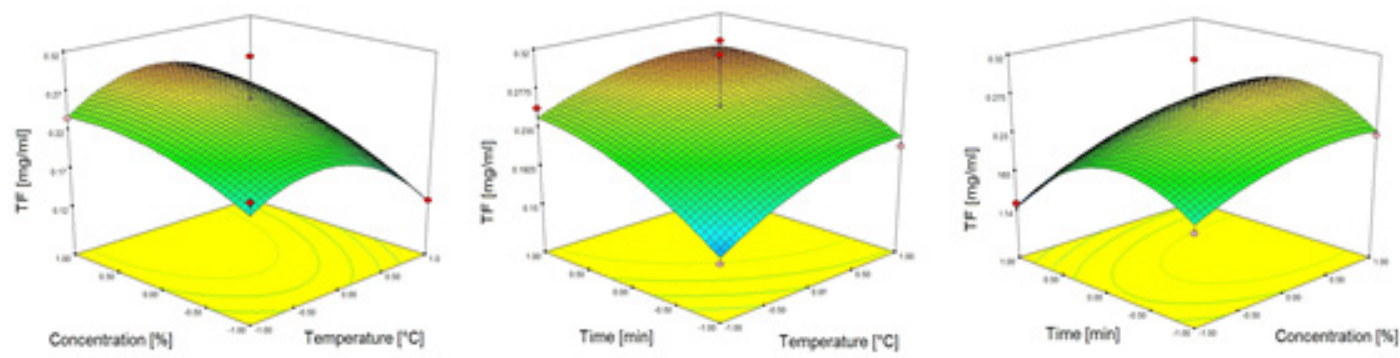

Figure 2. The influence of the investigated parameters on total flavonoids content

Simplicity and low cost are the main reasons for combining thin-layer chromatography (TLC) with UVspectrophotometry for apigenin determination. Apigenin contents in the analysed A-CLF liquid extracts were in the range from 0.0884 to $0.179 \mathrm{mg} / \mathrm{ml}$. Although the coefficient of multiple determination was satisfactory and indicated a good fit of experimental and theoretical values, the coefficient of variance was rather low (Table 2), the testing for the lack of fit suggested that the model did not represent the observed experiment well (Table 3).
F-value for the lack of fit was high, as it was the case with the model for the total phenolics content. However, $p$-value for the lack of fit in this was very close to the critical point $(p<0.05)$ comparing to the one for total phenolics. The apigenin content was significantly influenced by linear terms of the concentration and time, while the temperature influence was rather insignificant, as it was the case with the interaction between independent variables $(p>0.1)$. A negative quadratic effect of the ethanol concentration was the same as it was the case with TP 
and TF, which also indicated that there was a saddle point at certain concentration. After this point, the yield of apigenin started to decrease, as it was the case with TP and TF.

Optimal process values of the temperature, solvent concentration and time for the preparation of A-CLF extracts with the maximum content of apigenin could be calculated by using the equation (3).

$$
\begin{aligned}
& Y=0.16516+0.0074 X_{1}-0.0135 X_{2}+0.0143 X_{3}- \\
& -0.00523 X_{1}^{2}-0.01783 X_{2}^{2}-0.01313 X_{3}^{2}- \\
& -0.0085 X_{1} X_{2}+1.3 X_{1} X_{2}-5.23 X_{2} X_{3}
\end{aligned}
$$

where $Y$ represents the apigenin content, $X_{1}$ the extraction temperature, $X_{2}$ the solvent concentration and $X_{3}$ the extraction time.

The influence of the investigated parameters on the apigenin yield is shown in the Figure 3. As in previous cases, the influence of the concentration was most obvious. A higher slope could be noted at lower values of the concentration and after a certain point, the apigenin yield started to decrease. According to this, it is expected that the optimum value of the concentration is beneath the middle level of the independent variable. In the case of other two variables, the apigenin content was constantly growing with the increase of temperature and time, and optimum values are expected to be above the middle point of two variables.
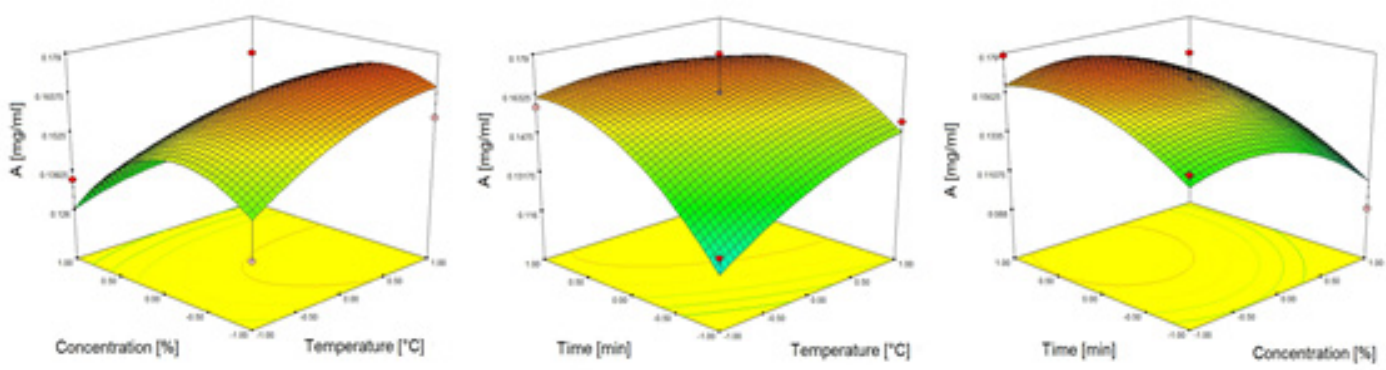

Figure 3. Response surface plots showing the effects of the investigated parametars on the apigenin content

Determination and validation of optimal conditions

In chemical engineering, all processes demand optimization as a crucial step. This includes a detailed investigation of all the process parameters in order to obtain the optimum conditions for a particular process. This leads to rationalization in the process operations in terms of lowering costs and achieving a higher quality of the final product. In this work RSM was applied for optimization, which simultaneously optimizes several levels of process variables to attain the best system performance [39].

Second order polynomial models obtained in this study were utilized for each response in order to determine the optimum extraction conditions [28]. Two optimized systems were investigated in this study. Due to the number of health benefits of apigenin [40], the main attention was to deploy te optimized extraction conditions for its yield. On the other hand, it was important to retain high contents of other polyphenolic compounds in liquid extracts due to their potential additive and synergistic effects.

The first system (System I) was developed in order to maximize the yields for TP, TF and A with the highest level of importance for the apigenin content (5) and the lowest levels for TP and TF (1). The results of optimized parameters, predicted and observed values are reported in Table 4. The validation of experiments was performed under the optimized conditions in order to estimate concurrence of predicted and observed values. The model showed good prediction for two output variables (TF and A). However, the observed values of TP were bellow expected. This could be due to a significant lack of fit for the predicted model.

In the second system (System II), the focus was on apigenin as the main flavonoid compound responsible for the spasmolytic activity of A-CLF liquid extracts, therefore other outputs (TP and TF) were not investigated. According to the results presented in Table 5, a good correlation between the predicted and observed values confirmed that the response model was suitable for the intended optimization. 
Table 5. The comparison between the predicted and observed values for the response variables

\begin{tabular}{ccc}
\hline & System I & System II \\
\hline Optimized condition & 80.0 & 73.6 \\
Temperature $\left.{ }^{\circ}{ }^{\circ} \mathrm{C}\right]$ & 62.0 & 60.8 \\
Concentration [\%] & 50.4 & 46.0 \\
Time [min] $^{\circ}$ & Predicted values $^{\mathrm{a}}$ & \\
TP & $1.615 \pm 0.180$ & \\
TF & $0.276 \pm 0.040$ & $0.172 \pm 0.020$ \\
A & $0.171 \pm 0.020$ & \\
& Observed values & \\
TP & $1.270 \pm 0.01$ & \\
TF & $0.303 \pm 0.002$ & $0.178 \pm 0.004$ \\
A & $0.184 \pm 0.005$ & \\
\hline
\end{tabular}

a Mean $\pm 95 \%$ confidence interval

b Mean \pm SD (standard deviation; $n=3$ )

Optimal conditions for the highest phenolic content were determined at the temperature of $80^{\circ} \mathrm{C}, 61 \%$ ethanol and the time of $60 \mathrm{~min}$. In order to obtain the maximum of flavonoids in A-CLF liquid extracts the optimal conditions were: the temperature of $71^{\circ} \mathrm{C}$, the ethanol concentration of $68.2 \%$ and the time of $57.4 \mathrm{~min}$.

\section{Conclusion}

Liquid extracts of autofermented chamomile ligulated flowers can be used as a potential rich source of apigenin and also as a rich source of phenols and other flavonoids. Response surface methodology (RSM) was applied for the extraction of total phenols (TP), total flavonoids (TF) and the compound of the greatest interest, apigenin. Optimized extraction conditions for each response (TP, TF and A) individually and collectively for all responses were determined. The first system (System I) included maximization of all three responses with the highest level of importance for the apigenin (5) content and the lowest levels for TP and TF (1), while the second system (System II) was only based on maximization of apigenin. Experimental validation was performed for two investigated systems. Considering the fact that the extracts with higher concentration of apigenin may have more pronounced pharmacological activity, these results can be useful for developing new A-CLF-based products. Scale-up from a laboratory to the industrial level would probably need further investigation, prior to the full implementation.

\section{Acknowledgment}

The financial support from the Serbian Ministry of Education, Science and Technological Development, Project No. TR 31013 is gratefully acknowledged. We are grateful to Dr Dušan Adamović, Institute of Field and Vegetable Crops, Bački Petrovac, Serbia, for his support in providing the plant material.

\section{References}

[1] M. Blumenthal, Therapeutic guide to herbal medicines, the complete German commission and monographs, Integrative Medicine Communications, Austin, Texas 2000.

[2] C. Mann, E. Staba, In: Herbs, spices and medicinal plants: recent advances in botany, horticulture, and pharmacology, L.E. Craker, J.E. Simon, Eds., Oryx Press, Arizona 1986, pp. 235-280.

[3] A.G. Maiche, P. Grohn, H. Maki-Hokkonen, Effect of chamomile cream and almond ointment on acute radiation skin reaction, Acta Oncologica, 30 (1991) 395-396.

[4] P. Fidler, C.L. Loprinzi, J.R. O'Fallon, Prospective evaluation of a chamomile mouthwash for prevention of 5-FU-induced oral mucositis, Cancer, 77 (1996) 522-525

[5] B. Li, H. Pinch, D.F. Birt, Influence of vehicle, distant topical delivery, and biotransformation on the chemopreventive activity of apigenin, a plant flavonoid, in mouse skin. Pharmaceutical Research, 13 (1996) 1530-1534.

[6] H. Viola, C. Wasowski, M. Levi de Stein, C. Wolfman, R. Silveira, F. Dajas, J.H. Medina, A.C. Paladini, Apigenin, a component of Matricaria recutita flowers, is a central benzodiazepine receptors-ligand with anxiolytic effects, Planta Medica, 61 (1995) 213-216.

[7] J.S. Cauffield, H.J. Forbes, Dietary supplements used in the treatment of depression, anxiety, and sleep disorders, Lippincott's primary care practice, 3 (1999) 290-304.

[8] M.M. Larzelere, P. Wiseman, Anxiety, depression, and insomnia, Primary Care, 29 (2002) 339-360.

[9] Z. Weizman, S. Alkrinawi, D. Goldfarb, C. Bitran, Efficacy of herbal tea preparation in infantile colic, Journal of Pediatrics, 122 (1993) 650-652.

[10] S. De la Motte, S. Bose-O'Reilly, M. Heinisch, F. Harrison, Double-blind comparison of an apple pectin-chamomile extract preparation with placebo in children with diarrhea, 
Arzneimittel Forschung, 47 (1997) 1247-1249.

[11] M.M. Presibella, L. De Biaggi Villas-Bôas, K.M. da Silva Belletti, C.A. de Moraes Santos, A.M. Weffort-Santos, Comparison of chemical constituents of Chamomilla recutita (L.) Rauschert essential oil and its antichemotactic activity. Brazilian Archives of Biology and Technology,49 (2006) 717-724.

[12] S. Shukla, S. Gupta, in Bioactive foods in promoting health: Fruits and vegetables, R. Ross, V.R. Predy, Eds, Academic Press, London 2009, pp. 663-689.

[13] R. Avallone, P. Zanoli, L. Cosi, G. Cannazza, M. Baraldi, Benzodiazepine like compounds and GABA in flower heads of Matricaria chamomilla. Phytotherapy Research 10 (1996) 177-179.

[14] P. Mak, Y.K. Lejny, W.Y. Tang, C. Harwood, S.M. Ho, Apigenin suppresses cancer cell growth through ER $\beta$, Neoplasia. 8 (2006) 896-904.

[15] S. Mirzoeva, N. D. Kim, K. Chiu, C. A. Franzen, R. C. Bergan, J. C. Pelling, Inhibition of HIF-1 alpha and VEGF expression by the chemopreventive bioflavonoid apigenin is accompanied by Akt inhibition in human prostate carcinoma PC3-M cells, Molecular Carcinogenesis, 47 (2008) 686-700.

[16] M. Repcák, T. Krausová, Phenolic glucosides in the course of ligulate flower development in diploid and tetraploid Matricaria chamomilla, Food Chemistry, 116 (2009) 19-22.

[17] V. Švehlíková, R.N. Bennett, F.A. Mellon, P.W. Needs, S. Piacente, P.A. Kroon, Y. Bao, Isolation, identification and stability of acylated derivates of apigenin 7-O-Glucoside from chamomile (Chamomilla recutita [L.] Rauschert), Phytochemistry, 65 (2004) 2323-2332.

[18] B. Pekić, Z. Zeković, Investigation of Chamomile fermentation, Biotechnology letters, 16 (1994)1323-1328.

[19] B. Pekić, Z. Zeković, Ž. Lepojević, Investigation of apigenin-7-O- $\beta$-glucoside hydrolysis by $\beta$-glucosidase from almonds. Biotechnology Letters, 16 (1994) 229-234.

[20] R. Maier, W. Kreis, R. Carle, E. Reinhard, Partial purification and substrate specificity of a $\beta$-clucosidase from Chamomilla recutita, Planta Medica, 57 (1991) A84-A85.

[21] G.E.P. Box, D.W. Behnken, Some new three level designs for the study of quantitative variables. Technometrics, 2 (1960) 455-475.

[22] C.Y. Gan, N.H.A. Manaf, A.A. Latiff, Optimization of alcohol insoluble polysaccharides (AIPS) extraction from the Parkia speciosa pod using response surface methodology (RSM), Carbohydrate Polymers, 79 (2010) 825-831.

[23] C.Y. Gan, A.A. Latiff, Extraction of antioxidant pecticpolysaccharide from mangosteen (Garcinia mangostana) rind: optimization using response surface methodology, Carbohydrate Polymers, 83 (2011) 600-607.

[24] X. Yin, Q. You, Z. Jiang, Optimization of enzyme assisted extraction of polysaccharides from Tricholoma matsutake by response surface methodology. Carbohydrate Polymers, 86 (2011) 1358-1364.

[25] Z. Zeković, A. Cvetanović, B. Pavlić, J. Švarc-Gajić, M. Radojković, Optimization of the Polyphenolics Extraction from Chamomile Ligulate Flowers Using Response Surface Methodology, International Journal of Plant Research, 4 (2014) 43-50.

[26] C. L. Ye, C. J. Jiang, Optimization of extraction process of crude polysaccharides from Plantago Asiatica L. by response surface methodology, Carbohydrate Polymers, 84 (2011) 495-502.

[27] K. Zhong, Q. Wang, Optimization of ultrasonic extraction of polysaccharides from dried longan pulp using response surface methodology, Carbohydrate Polymers, 80 (2010) 19-25.

[28] M. Radojković, Z. Zeković, R. Sudar, S. Jokić, A. Cvetanović, Optimization of solid-liquid extraction of antioxidants and saccharides from black mulberry fruit by response surface methodology, Journal of Food and Nutrition Research, 52 (2013) 146-155.

[29] A. Cvetanović, J. Švarc-Gajić, P. Mašković, S.Savić, LJ.Nikolić, Antioxidant and biological activity of chamomile extracts obtained by different techniques: perspective of using superheated water for isolation of biologically active compounds, Industrial Crops and Products, In Press, 2014, http://dx.doi.org/10.1016/j.indcrop.2014.09.044.

[30] V.L, Singleton, J.A. Rossi Jr, Colorimetry of total phenolis with phosphomolybdic-phosphotungstic acid reagents. American Journal of Enology and Viticulture, 16 (1965) 144-158.

[31] M.P. Kähkönen, A.I. Hopia, H.J. Vuorela, J.P. Rauha, K. Pihlaja, T.S. Kujala, M. Heinonen, Antioxidant activity of plant extracts containing phenolic compounds, Journal of Agricultural and Food Chemistry, 47 (1999) 3954-3962.

[32] K.R. Markham, in: Plant Phenolics, J.B. Harborne, P.M. Dey, Eds., Academic Press, London, 1989.

[33] B. Pekic, Ž. Lepojević, B. Slavica, Determination of apigenin and apigenin-7-O-â-glucoside in the Matricaria Chamomilla ligulate flowers, Archive for Pharmacy, 39 (1989) 169-174.

[34] D. Montgomery, Design and Analysis of Experiments, John Wiley \& Sons, New York, 2001.

[35] E.M. Silva, H. Rogez, Y. Larodelle, Optimization of extraction of phenolics from Inga edulis leaves using response surface methodology, Separation and Purification Technology, 55 (2007) 381-387.

[36] Z. Zeković, Determination, extraction and chemical transformations of Chamomile (Matricaria chamomilla L.) flavonoids, Magister thesis, Faculty of Technology, University of Novi Sad, 1993.

[37] G.E.P. Box, N. R. Draper, Empirical Model Building and Response Surfaces, John Wiley \& Sons, New York, 1987.

[38] R.H. Myers, D.C. Montgomery, Response Surface Methodology: Process and Product Optimization Using Designed Experiments, John Wiley \& Sons, New York, NY, 1995.

[39] M.A. Bezerra, R.E. Santelli, E.P. Oliveira, L.S. Villar, L.A. Escaleira, Response surface methodology (RSM) as a tool for optimization in analytical chemistry, Talanta, 76 (2008) 965-977.

[40] J. O'Prey, J. Brown, J. Fleming, P.R. Harrison, Effects of dietary flavonoids on major signal transduction pathways in human epithelial cells, Biochemical Pharmacology, 66 (2003) 2075-2088. 
Izvod

\section{OPTIMIZACIJA PROCESA EKSTRAKCIJE FLAVONOIDA IZ FERMENTISANIH CVETOVA KAMILICE}

Zoran Zeković1, Aleksandra D. Cvetanović ${ }^{1}$, Branimir M. Pavlić1, Jaroslava V. Švarc-Gajić ${ }^{2}$ Marija M. Radojković ${ }^{1}$

(ORIGINALNI NAUČNI RAD)

UDK 547.972.3

${ }^{1}$ Tehnološki fakultet, Katedra za biotehnologiju i farmaceutsko inženjerstvo, Novi Sad, Srbija

${ }^{2}$ Tehnološki fakultet, Katedra za primenjene i inženjerske hemije, Novi Sad, Srbija

U prikazanom istraživanju u cilju ispitivanja uticaja ekstrakcionih parametara na ekstrakcioni prinos ukupnih fenola (UF), flavonoida (UFL) i apigenina (A) iz ekstrakata autofermentisanih jezičastih cvetova kamilice, korišćena je metoda odzivne površine (RSM). Temperatura, koncentracija etanola i vreme ekstrakcije su izabrani kao nazavisno promenljive, a njihove vrednosti definisane na osnovu preliminarnih eksperimentalnih rezultata, kao i na osnovu literaturnih podataka. Korišćeni Box-Behnken dizajn eksperimenata sastojao se od 17 eksperimentalnih koraka sa pet ponavljanja u centralnoj tački. Polinomna jednačina drugog reda korišćena je za predviđanje odgovora sistema. Definisani optimalni uslovi pri kojima se ostvaruje maksimalni prinos UF, UFL i A podrazumevali su temperaturu od $80{ }^{\circ} \mathrm{C}$, koncentraciju etanola od $62 \%$ i vreme ekstrakcije u trajanju od 50,4 min. Sa druge strane maksimalni prinos apigenina mogao bi se očekivati pri temperaturi ekstrakcije od $73,6{ }^{\circ} \mathrm{C}$, koncentraciji etanola od $60,8 \%$ i vremenu ekstrakcije od 46 min. Verifikacija eksperimenata urađena je pri prethodno definisanim uslovima. Eksperimentalno dobijene vrednosti bile su u korelaciji sa predviđenim, što ukazuje na pogodnost korišćenog modela i uspešnost korišćenja RSM metode za optimizaciju uslova ekstrakcije.
Ključne reči: kamilica, metoda odzivne površine (RSM), optimizacija, polifenoli, apigenin. 